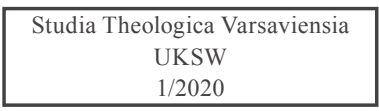

Ks. Przemyseaw Artemiuk

\title{
NURTY WSPÓŁCZESNEJ APOLOGII
}

\section{WSTEP}

W środowisku teologów fundamentalnych UKSW nowa apologia od lat budzi żywe zainteresowanie'. Fascynuje ich rozmach, różnorodność i siła współczesnych apologetów. Dostrzegając ten niezwykle dynamiczny fenomen, które cechuje się wielopostaciowością, wnikliwie analizują dzieła z kręgu nowej apologii. Nawiązują w ten sposób do badań realizowanych przez dawną Warszawską Szkołę Apologetyczną. Gwoli przypomnienia, od końca lat pięćdziesiątych (za moment jej powstania można przyjąć utworzenie 1 stycznia 1956 r. Zespołowej Katedry Apologetyki na Wydziale Teologicznym Akademii Teologii Katolickiej) systematycznie podejmowała ona refleksję nad apologiami, jednak czyniła to zgodnie z własną metodologią. W sposób naukowy dążyła bowiem do uzasadnienia prawdziwości roszczeń religii katolickiej i poddawała krytycznej ocenie

${ }^{1}$ Cf. P. Artemiuk, Renesans apologii, Płock 2016; P. Artemiuk, Wobronie spraw najważniejszych. Szkice o apologii, Poznań 2019; Bronić czy dialogować? O pewnym dylemacie chrześcijaństwa dzisiaj, red. H. Seweryniak, P. Artemiuk, Płock 2016; Powracanie apologii, red. M. Skierkowski, Płock 2013; H. Seweryniak, Apologia wiary i nowa ewangelizacja, „Communio” 1/2014, 5-20; H. Seweryniak, Apologia apologii „na dziennikarstwie”, w: Debaty UKSWordzkie, cz. 2, red. J. Sobkowiak, Warszawa 2017, 7-53; H. Seweryniak, Apologia i dziennikarstwo, Warszawa 2018. We wstępie wykorzystuję fragmenty mojej książki Renesans apologii. 


\section{STREAMS OF THE NEW APOLOGIA}

\section{INTRODUCTION}

Among fundamental theologians of the UKSW (the Cardinal Stefan Wyszyński University in Warsaw), the new apologia has been of great interest for years ${ }^{1}$. They are fascinated by the momentum, diversity and strength of modern apologists. Noticing this extremely dynamic phenomenon, which is characterised by its multiformity, they thoroughly analyse works from the circle of the new apologia. In this way, they refer to the research carried out by the former Warsaw School of Apologetics. Since the end of the 1950s (the moment of its establishment can be assumed to mark the creation of the Team Chair of Apologetics at the Faculty of Theology of the Academy of Catholic Theology on 1 January 1956), it had been systematically reflecting on apologies, but it did so according to its own methodology.

1 See Artemiuk, P. (2016). Renesans apologii, Płock; Artemiuk, P. (2019) W obronie spraw najważniejszych. Szkice o apologii, Poznań; Bronić czy dialogować? O pewnym dylemacie chrześcijaństwa dzisiaj, ed. Seweryniak, H., Artemiuk, P. (2016) Płock; Powracanie apologii, ed. Skierkowski, M. (2013) Płock; Seweryniak, H. Apologia wiary i nowa ewangelizacja, „Communio” 1/2014, 5-20; Seweryniak, H. Apologia apologii ,na dziennikarstwie”, in Debaty UKSWordzkie, part 2, ed. Sobkowiak, J. (2017) Warsaw, 7-53; Seweryniak, H. Apologia i dziennikarstwo, (2018) Warsaw. In the introduction, excerpts from the author's own book Renesans apologii are quoted. 
jej apologię ${ }^{2}$. Przyjmując religioznawczy punkt widzenia, ,apologetyka totalna" (określenie W. Kwiatkowskiego), badając apologię chrześcijaństwa, zwracała uwagę na wymiar aksjologiczny, czyli wartość normatywną, a dokładnie obecność sanctum w świadomości i działalności Jezusa z Nazaretu ${ }^{3}$ (chodziło w niej o „wyświetlenie wartości najstarszego i klasycznego systemu obronnego, pochodzącego od samego Jezusa"4), wskazując równocześnie, że to właśnie chrześcijaństwo łączy w sobie wszystkie wartości w stopniu najwyższym, co decyduje o jego absolutnie normatywnym charakterze. Projekt podjęty przez W. Kwiatkowskiego zakończył się stworzeniem apologetycznego sytemu naukowego jako samodzielnej dziedziny, zbliżonej do teologii i religioznawstwa ${ }^{5}$.

W spojrzeniu na apologijną rzeczywistość różni teologów fundamentalnych z UKSW od dawnych warszawskich apologetyków perspektywa, zakres poszukiwań oraz metodologia badań. Ci pierwsi, zajmujący się ,faktycznością, sensem i znakami wiarygodności zbawczego Objawienia Boga w Jezusie Chrystusie oraz jego uobecnieniem w misterium i wspólnocie Kościoła”, z szacunkiem odnoszą się do dawnej apologetyki, nie przyjmują jednak jej metodologii, sytuującej się w polu religioznawczym i przedteologicznym. Warto odnotować tylko, że klasyczna apologetyka kształtująca się na przestrzeni od XVI do XIX w., zachowując polemiczną postawę wobec oświecenia, wypracowała rozumowe racje przemawiające za chrześcijaństwem, a widząc w pozytywistycznym modelu nauk ideał, przeracjonali-

2 Cf. I.S. Ledwoń, Apologetyka, w: Leksykon teologii fundamentalnej, red. M. Rusecki, K. Kaucha, I.S. Ledwoń, J. Mastej, Lublin-Kraków 2002, 78-85.

3 „Innymi słowy, podkreśla W. Kwiatkowski, według ujęcia empirycznego, apologetyka totalna jest to krytyczne i systematyczne poznanie, z punktu widzenia aksjologicznego, przeprowadzonej przez Jezusa Chrystusa samoobrony siebie jako najwyższej wartości religijnej (Sanctum)"; W. Kwiatkowski, Apologetyka totalna, t. I, Warszawa 1961, 153.

${ }_{4}$ W. Kwiatkowski, Apologetyka totalna, t. II, Warszawa 1962, 103.

5 W. Kwiatkowski, Początki i rozwój Warszawskiej Szkoły Apologetycznej, „Studia Theologica Varsaviensia” 3/1965 nr 1, 6.

${ }^{6}$ H. Seweryniak, Teologia fundamentalna, t. I, Warszawa 2010, 52. 
Scientifically, it sought to justify the truthfulness of the claims of the Catholic religion and critically evaluated its apologia ${ }^{2}$. As far as religious studies are concerned, ,total apologetics" (the term used by W. Kwiatkowski), while researching the apologia of Christianity, drew attention to the axiological dimension, i.e. the normative value, namely the presence of sanctum in the consciousness and activity of Jesus of Nazareth ${ }^{3}$ it was about 'displaying the value of the oldest and

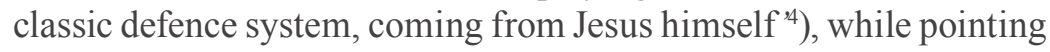
out that it is precisely Christianity that combines all values to the highest degree, which determines its absolutely normative character. The project undertaken by W. Kwiatkowski ended with the creation of an apologetic scientific system as an independent field, similar to theology and religious studies 5 .

In looking at the apological reality, fundamental theologians from the UKSW differ from the former Warsaw apologists in terms of their perspective, scope of research and methodology. The former, dealing with 'the facticity, as well as meaning and signs of credibility of the salvific revelation of God in Jesus Christ and his presence in the mystery and community of the Church' ${ }^{6}$, respectfully refer to the former apologetics, but do not accept its methodology, which is situated in the religious and pre-theological field. However, it is worth noting that the classic apologetics, which was formed between the sixteenth and nineteenth centuries, while maintaining a polemical attitude towards the Enlightenment, developed rational arguments in favour of Christianity, and seeing the positivist model of science as

2 See Ledwoń, I.S., Apologetyka, in Leksykon teologii fundamentalnej, ed. Rusecki, M., Kaucha, K., Ledwoń, I.S., Mastej, J., (2002) Lublin-Kraków, 78-85.

3 „In other words, Kwiatkowski emphasises that, according to empirical approach, total apologetics is a critical and systematic cognition, from an axiological point of view, of Jesus Christ's self-defence as the highest religious value (Sanctum)"; Kwiatkowski, W. (1961), Apologetyka totalna, vol. 1, Warsaw, 153.

${ }^{4}$ Kwiatkowski, W. (1962) Apologetyka totalna, vol. 2, Warsaw, 103.

5 Kwiatkowski, W. Początki i rozwój Warszawskiej Szkoły Apologetycznej, „Studia Theologica Varsaviensia” 3/1965 no. 1, 6.

${ }^{6}$ Seweryniak, H. (2010) Teologia fundamentalna, vol. 1, Warsaw, 52. 
zowała własny sposób argumentacji. Tworząc kryteria obiektywne, uległa pokusie ekstrynsecyzmu i nie podjęła pogłębionej refleksji nad Objawieniem ${ }^{7}$. Podejmując naukową analizę nowej apologii, dokonują jej w perspektywie fundamentalnoteologicznej, chcą bowiem rozumem oświeconym wiarą spojrzeć na tę rzeczywistość.

Czym jest według teologów fundamentalnych z UKSW nowa apologia? Jak ją definiują? Nowa apologia dokonuje się w aktualnych czasie i przestrzeni. Jej kontekst to płynny świat, który rozmywa i poddaje dekonstrukcji podstawowe pojęcia. Dominuje w nim dyktatura politycznej poprawności, wieści on przegraną Boga i zmierzch christianitas, porzuca przy tym metafizykę i ogłasza tryumf nieokreśloności. Świat ten jest równocześnie zmęczony bezideowością i tęskni za powrotem do trwałych wartości. Nie potrafi jednak porzucić ciemności i otworzyć się na światło, cechuje go bowiem utrata wiary w prawdy transcendentne i nieufność wobec wszelkiego rodzaju religii, nierzadko identyfikowanych z fundamentalizmem i przemocą.

Aktualny kontekst decydująco wpływa i kształtuje przedmiot nowej apologii. Tradycyjnie definiowano go jako obronę wiary i wartości chrześcijańskich, jednak z perspektywy najnowszych badań takie stwierdzenie jest niewystarczające. Chcąc całościowo spojrzeć na przedmiot nowej apologii, należy go poszerzyć i dostrzec, iż obrona zaczyna się już zdecydowanie wcześniej, w obrębie samej cywilizacji, a jej przestrzenią jest najpierw człowiek. Współczesna apologia staje się zatem obroną jego tożsamości, która wyraża się w pamięci historycznej, odpowiedzialności za swoje czyny, nienaruszalności życia oraz kulturze ukazującej drugą, duchową przestrzeń. Obok zmagania o człowieka, przedmiotem obrony jest naturalnie samo chrześcijaństwo i jego obecność w świecie. Nowa apologia walczy więc o chrześcijańską duszę, uzasadnia istnienie ewangelicznego katolicyzmu, wykazuje racjonalność chrześcijaństwa oraz szuka przestrzeni dla preewangelizacji. W końcu staje w obronie istotnych treści samej wiary i odpiera zarzuty uderzające w serce chrześcijaństwa.

${ }^{7}$ Cf. Ibidem, 26-30. 
an ideal, it renationalised its own way of argumentation. By creating objective criteria, it succumbed to the temptation of extremism and did not undertake an in-depth reflection on Revelation ${ }^{7}$. By undertaking a scientific analysis of the new apologia, they do so from a fundamental theological perspective, seeking to look at this reality with reason enlightened by faith.

What is the new apologia, according to fundamental theologians from the UKSW? How do they define it? A new apologia takes place in real time and space. Its context is a fluxional world, which blurs and deconstructs basic concepts. It is dominated by a dictatorship of political correctness, it announces the defeat of God and the twilight of Christianitas, it abandons metaphysics and announces the triumph of indeterminacy. At the same time, this world is tired of being idealess and longing for a return to lasting values. However, it is unable to abandon darkness and open itself to light, as it is characterized by a loss of faith in transcendent truths and distrust in all kinds of religions, often identified with fundamentalism and violence.

The current context decisively influences and shapes the subject of the new apologia. Traditionally, it used to be defined as a defence of the faith and Christian values, but from the perspective of recent research, this statement has appeared to be insufficient. If we want to look at the subject of the new apologia in its entirety, we should broaden it and see that the defence starts much earlier, within civilisation itself, and its space is first of all man. The contemporary apologia therefore becomes a defence of his identity, which is expressed in historical memory, responsibility for his actions, the inviolability of life and a culture that shows a second, spiritual space. Alongside the struggle for man, the object of defence is naturally Christianity itself and its presence in the world. The new apologia therefore fights for the Christian soul, justifies the existence of evangelical Catholicism, shows the rationality of Christianity and seeks space for pre-evangelisation. Eventually, it stands up for the essential content

${ }^{7}$ See Ibidem, 26-30. 
Syntetycznie ujmując przedmiot nowej apologii, można stwierdzić, iż chce ona ocalić człowieka, broniąc jego tożsamości, argumentuje za sensem obecności chrześcijaństwa w świecie i zmagając się z zarzutami przeciwko Chrystusowej wierze, dostarcza racji przemawiających za nią. Realizując własną misję, wychodzi zdecydowanie poza przestrzeń typowo religijną i doskonale porusza się także w ,świeckiej” rzeczywistości. W ten sposób staje się nurtem szerszym, ponadkonfesyjnym lub niekonfesyjnym, ale katolicyzm traktuje zawsze jako swoje źródło, życiodajne podłoże, pojawiające się w horyzoncie uzasadnienia. Głównym zadaniem nowej apologii pozostaje jednak niezmiennie obrona nadprzyrodzonego charakteru chrześcijańskiego Objawienia w aktualnym kontekście, ale również jasne rozeznanie tego kontekstu. Realizując własną misję, apologia formułuje racje wobec zarzutów pochodzących z zewnątrz (apologia ad extra) oraz szuka niezbędnych argumentów, tak by można było budować własną pewność wiary (apologia ad intra).

H. Seweryniak, w swojej najnowszej pracy „Apologia i dziennikarstwo", charakteryzując fenomen nowej apologii, podaje jej trzy konstytutywne cechy: po pierwsze, broni ona „ogromnego obszaru wyjaśniania i rozumienia świata, człowieka i jego egzystencji”"; po drugie, jest odpowiedzią na zmasowany program „nowej lewicy”, potężną anty-ewangelizację i ,dyktaturę relatywizmu”; po trzecie, „uprawiają ją przede wszystkim wybitni dziennikarze i publicyści lub naukowcy (filozofowie, teologowie, prawnicy, psychologowie, socjologowie, medioznawcy) o zacięciu publicystycznym, medialnym, a także dobrze władający piórem lub oswojeni z nowymi mediami politycy konserwatywni ${ }^{10}$. Samą zaś apologię H. Seweryniak definiuje następująco: „dokonywana w aktualnym kontekście czasu, intelektualna i praktyczna obrona cywilizacji euroatlantyckiej, ufundowanej na: chrześcijańskiej koncepcji osoby ludzkiej, szacunku dla praw człowieka, uznaniu naturalnej różnicy płci, niepodważalności

\footnotetext{
${ }^{8}$ H. Seweryniak, Apologia i..., op. cit.,12.

9 Cf. Ibidem, 14-16.

10 Ibidem, 16.
} 
of the faith itself, and refutes accusations that strike at the heart of Christianity.

Synthetically speaking, the subject of the new apologia can be said to seek to save man by defending his identity, to argue for the sense of Christianity's presence in the world, and, by struggling with accusations against Christ's faith, it provides the rationale behind it. In carrying out its own mission, it goes far beyond the typical religious space and also moves perfectly within the, secular' reality. In this way it becomes a broader, over-confessional or non-confessional trend, but Catholicism is always treated as its source, a life-giving ground, appearing in the horizon of justification. However, the main task of the new ap apologia ology remains the defence of the supernatural nature of Christian Revelation in the current context, but also a clear understanding of that context. In carrying out its own mission, the apologia formulates its arguments against accusations coming from outside (apologia ad extra) and seeks the necessary arguments in order to build its own confidence in the faith (apologia ad intra).

In his latest work „Apologia Theory and Journalism”, characterising the phenomenon of the new Apologia, Seweryniak gives it three constitutive features: firstly, it defends ,a vast area of explaining and understanding the world, man and his existence"s; secondly, it is a response to the massive programme of the ,new left wing", the powerful anti-evangelisation and the „dictatorship of relativism”; thirdly, it is ,practised above all by eminent reporters and journalists or scientists (philosophers, theologians, lawyers, psychologists, sociologists, media experts) with journalistic and media fierceness, as well as pen-masters or conservative politicians accustomed to the new media ${ }^{10}$. And the Apologia itself is defined by Seweryniak as „the intellectual and practical defence, in the current context of time, of the Euro-Atlantic civilisation founded on: the Christian concept of the human person, respect for human rights, recognition of the

\footnotetext{
${ }^{8}$ Seweryniak, H. Apologia i..., op. cit.,12.

9 See Ibidem, 14-16.

10 Ibidem, 16.
} 
małżeństwa między kobietą i mężczyzną i stworzonej przez nich rodziny oraz respektowaniu najwyższej wartości życia ludzkiego od poczęcia do naturalnej śmierci”"11.

Analizując nową apologię, nietrudno dostrzec jej obszary zainteresowań. Pisałem o nich przed czterema laty w mojej rozprawie habilitacyjnej, dokonując ich szczegółowej charakterystyki ${ }^{12}$. Najnowsze badania pozwalają także wyróżnić oryginalne nurty, które pojawiają się wśród apologetów. Warto je dostrzec i poddać analizie.

\section{NURT ANTROPOLOGICZNY}

Obrona człowieka jest bardzo wyraźnym nurtem współczesnej apologii $^{13}$. Dzieje się tak przynajmniej z kilku powodów. Po pierwsze, dlatego, że pozbawia się go właściwej mu tożsamości i podejmuje dyskusję nad istotą człowieczeństwa. Przesunięcia terminologiczne wynikają najczęściej z bieżących sporów antropologicznych. Stają ich odbiciem. W efekcie czego, podejmowane są próby dekonstrukcji podstawowych pojęć antropologicznych. Chodzi o ich redefinicję, czyli sfomułowanie istoty człowieczeństwa na nowo, w odmiennych, zmieniających się warunkach i kulturze, które mają istotny wpływ na człowieka. Najlepiej to widać w sporze o rozumienie płci.

Jeszcze całkiem niedawno ani słowa ,gender”, ani tym bardziej „genderyzm" nikt specjalnie nie kojarzył. Dzisiaj oba terminy robią zawrotną karierę. Należy je najpierw wyjaśnić, aby dostrzec istotną różnicę między nimi. Gender to „kulturowy i społeczny sposób przeżywania płciowości" ${ }^{14}$, obok niego funkcjonuje naturalnie termin płeć (angielskie sex), przez który rozumiemy psychofizyczne bycie kobietą

11 Ibidem.

12 Cf. P. Artemiuk, Renesans..., op. cit., 219-541.

13 Cf. T.P. Terlikowski, Moralny totalitaryzm, Warszawa 2006; T.P. Terlikowski, Nowa kultura życia. Apologia bioetyki katolickiej, Warszawa 2009; T.P. Terlikowski, Faktura na zabijanie. Wspótczesny przemyst śmierci, Bytom 2013; T.P. Terlikowski, Sprawa profesora Chazana. Kulisy manipulacji, Warszawa 2014.

14 M. Zięba, Kościót między gender a genderyzmem, w: M. Zięba, Kłopot za kłopotem. Katolik w dryfującej Europie, Poznań 2015, 25. 
natural gender difference, the indisputability of marriage between a man and a woman and the family they have created and respect for the supreme value of human life from conception to natural death"11.

Analysing the new apologia, it is not difficult to see its areas of interest, which were covered in the aouthor's habilitation thesis four years ago, along with their detailed characteristics ${ }^{12}$. The latest research also distinguishes the original currents that appear among apologists. These are well worth noticing and analysing.

\section{ANTHROPOLOGICAL STREAM}

The defence of man is a very clear trend in contemporary apologia ${ }^{13}$, and there are at least several reasons behind this. Firstly, because it deprives people of their proper identity and discusses the essence of humanity. The terminological shifts most often result from current anthropological disputes. They become a reflection of them. As a result, attempts are made to deconstruct basic anthropological concepts. The aim is to redefine them, that is to say, to re-formulate the essence of humanity again, in different, changing conditions and cultures that have a significant impact on people. This can be best seen in the dispute over understanding the gender.

Not long ago, nobody really associated the word gender [in the Polish language], let alone genderism. Today, both terms make a dizzying career [translator's note: in Poland]. They must first be clarified in order to see the significant difference between them. Gender is a ,cultural and social way of experiencing sexuality ${ }^{14}$, alongside it there is naturally the term sex, by which we mean being

11 Ibidem.

12 See Artemiuk, P. Renesans..., op. cit., 219-541.

13 See Terlikowski, T.P. (2006) Moralny totalitaryzm, Warsaw; Terlikowski, T.P. (2009) Nowa kultura życia. Apologia bioetyki katolickiej, Warsaw; Terlikowski, T.P. (2013) Faktura na zabijanie. Współczesny przemyst śmierci, Bytom; Terlikowski, T.P. (2014) Sprawa profesora Chazana. Kulisy manipulacji, Warsaw.

14 Zięba, M. Kościół między gender a genderyzmem, in: Zięba, M. (2015) Kłopot za kłopotem. Katolik w dryfującej Europie, Poznań, 25. 
lub mężczyzną. Tym, co istotnie różni się od gender, jest genderyzm. Nie jest on nauką, chociaż różnej maści specjaliści starają się wmówić nam coś innego. Nie oznacza również dążenia do równości kobiet i mężczyzn. „Chyba, że przez równość rozumieć tożsamość, a przez wyrównanie szans - rzecz przeciw której nikt rozsądny nie protestuje - likwidację różnic"15. Czym w takim razie jest? Genderyzm to „kolejna radykalna ideologia postoświeceniowa”"16 której źródłem jest „sprzeciw wobec Tradycji i natury. To co naturalne - podział na męskość i kobiecość, na dwie różne płci - ma zostać zniesione i przekroczone. Tak jak komuniści chcieli znieść własność, upatrując w niej źródło wszelkiego zła, tak genderyści zamierzają pozbyć się płci. Albo też, ściślej mówiąc, odebrać jej wszelkie znaczenie" "17. Ideologia ta chce „tworzyć taką kulturę i takie prawodawstwo, które minimalizując lub wręcz ignorując ludzką płciowość (sex), [zredukuje ją] głównie do elementu kulturowego i [wprowadzi] całkowitą zmienność ról mężczyzny i kobiety w społeczeństwie"18. Genderyzm zatem jest niezwykle niebezpieczną ideologią. Nie liczy się bowiem z ustaleniami nauki. „Ani bowiem genetyka, ani neurobiologia, ani medycyna nie negują istotnych różnic w męskim i żeńskim genotypie, $w$ budowie i funkcjonowaniu mózgu oraz budowie anatomicznej mężczyzny i kobiety" ${ }^{\prime 19}$. Program, który propagują zwolennicy tej ideologii, jest aż nazbyt wyraźny: całkowita reedukacja. Należy zatem ,usunąć z umysłów to, co od tysiącleci było dla ludzkości oczywistością: nawyk rozróżniania mężczyzn i kobiet; odróżnianie siły wzajemnego przyciągania seksualnego obu tych płci, na której opiera się egzystencja ludzkości w ogóle i dalsza jej egzystencja w szczególności, od wszystkich innych form zaspokajania popędu seksualnego; a także instytucjonalne uprzywilejowanie owej siły - w przeciwieństwie do tychże form - oraz poddanie jej pewnym

\footnotetext{
15 P. Lisicki, Wstęp, w: Gender. Kontrrewolucja, Kraków 2014, 6.

16 Ibidem.

17 Ibidem.

${ }_{18}$ M. Zięba, op. cit., 25.

19 Ibidem, 26.
} 
psychophysically a female or a male. What is fundamentally different from gender is genderism. It is not a science, although specialists of all sorts attempt to convince us otherwise. Neither does it mean seeking equality between men and women. 'Unless by equality we mean identity, and by equal opportunities - something that no reasonable person would protest against - the eradication of differences ${ }^{15}$. What is it then? Genderism is , another radical post-Enlightenment ideology ${ }^{16}$, the source of which is ,opposition to Tradition and nature. What is natural - the division into being a male and a female, into two different sexes - is to be abolished and transcended. Just as the Communists wanted to abolish property, seeing it as the source of all evil, genderists intend to get rid of gender. Or, to be more precise, to take away all meaning from it ${ }^{17}$. This ideology wants to ,create such a culture and such legislation that, by minimizing or even ignoring human sexuality (sex), [reduces it] mainly to a cultural element and [introduces] a complete change in the roles of a man and a woman in society" 18 . Genderism is therefore an extremely dangerous ideology. It does not take into account the findings of science. „Neither genetics, nor neurobiology, or medicine negate the significant differences in the male and female genotypes, in the structure and functioning of the brain and in the anatomical structure of man and woman"19. The programme that the supporters of this ideology advocate is all too clear: complete re-education. It is therefore necessary to:

(...) remove from our heads a millennia-old habit of humankind: the habit of distinguishing men from women. This includes extinguishing the fundamental truth that mutual sexual attraction between man and woman forms the basis of humankind's current and

\footnotetext{
15 Lisicki, P. (2014) Wstęp, in: Gender. Kontrrewolucja, Kraków, 6.

16 Ibidem.

17 Ibidem.

${ }_{18}$ M. Zięba, op. cit., 25.

19 Ibidem, 26.
} 
regułom humanizacji”"20. Ostatecznym celem tej reedukacji jest likwidacja ludzkie sposobu bytowania. „Powinniśmy się wyemancypować z naszej natury" ${ }^{21}$ - przekonują genderyści.

Po drugie, apologia człowieka dokonuje się w dobie mocno zakorzenionego już sporu dotyczącego jego życia (cywilizacja śmierci versus cywilizacja życia). Współcześni apologeci bronią istnienia człowieka, które rozciąga się od chwili poczęcia do naturalnej śmierci. W zmaganiach tych towarzyszy im doskonała znajomość prawideł bioetycznych. Wyraźnie występują przeciwko coraz agresywniejszej mentalności eutanazyjnej (mens eutanasica), w której człowiek chce całkowicie panować nad ludzkim życiem, odrzucając jego godność. Apologeci nie zgadzają się na dyktaturę biotechnologii. Ich zdaniem, niezwykle niebezpieczne są próby poddania kwestii życia ludzkiego imperatywowi technologicznemu, który, głosząc „,co jest możliwe technicznie, powinno zostać zrealizowane", stara się zrealizować nawet najbardziej niepokojące projekty antropologiczne.

Po trzecie, apologeci, broniąc człowieka, wskazują na zdecydowanie głębszą wartość jego życia. Jest on przecież przeznaczony do innej rzeczywistości. Wprawdzie żyje tutaj, na ziemi, jest zakorzeniony w tym świecie, jednak tęskni za wiecznością, przekracza ziemską rzeczywistość. Znakomicie oddaje to metafora „korzeni i skrzydeł" stworzona przez francuską apologetkę Ch. Delsol ${ }^{22}$. Jej zdaniem, człowieka nie można ograniczyć do rzeczywistości widzialnej. On sam tęskni za innym wymiarem życia. Jest do niego stworzony. Dlatego też próba odczytania człowieczeństwa jedynie w wymiarze horyzontalnym, staje się chybiona. Nie da się zamknąć ludzkiego życia w przestrzeni widzialnej. Kierunek wertykalny nadaje człowieczeństwu głębszy wymiar. Ludzka egzystencja, zdaniem H. Seweryniaka, posiada wiele znamion autotranscendencji. Są nimi pragnienie szczęścia, prawdy i bycia; zadziwienie cudem istnienia;

20 R. Spaemann, Wstęp, w: G. Kuby, Globalna rewolucja seksualna. Likwidacja wolności w imię wolności, przekład D. Jankowska, J. Serafin, Kraków 2012, 8.

21 Ibidem.

22 Cf. P. Artemiuk, W obronie..., op. cit., 143-157. 
future existence. Therefore it is distinguished from all other ways of satisfying people's drives, subjected to certain humanizing rules, and given privilege through institutionalization ${ }^{20}$.

The ultimate aim of this re-education is to eliminate the human way of life. „We are to emancipate ourselves from our nature”, ${ }^{21}$ argues the genderist.

Secondly, man's apologia is taking place at a time when the dispute over his life is already firmly rooted (the civilisation of death versus the civilisation of life). Contemporary apologists defend the existence of man, which stretches from conception to natural death. In these struggles, they are accompanied by an excellent knowledge of bioethical rules. They are clearly against an increasingly aggressive euthanasian mentality (mens eutanasica), in which man wants to control human life completely, rejecting his dignity. Apologists do not agree with the dictatorship of biotechnology. They believe that it is extremely dangerous to try to subject the issue of human life to a technological imperative which, by proclaiming, what is technically possible should be done', tries to implement even the most disturbing anthropological projects.

Thirdly, apologists, in defending man, point to a much deeper value of his life. After all, it is intended for a different reality. Although he lives here on earth, he is rooted in this world, he misses eternity, and exceeds earthly reality. This is perfectly reflected in the metaphor of ,roots and wings" created by the French apologist Ch. Delsol ${ }^{22}$. In her opinion, man cannot be limited to visible reality. He himself misses another dimension of life, which he is created for. That is

${ }^{20}$ Foreword (C) Robert Spaemann, (2012), in Kuby, G. The Global Sexual Revolution. Destruction of Freedom in the Name of Freedom; First published in English by LifeSite, (2015) an imprint of Angelico Press; English translation (C) James Patrick Kirchner, (2015)

${ }^{21}$ Ibidem.

${ }^{22}$ See Artemiuk, P. W obronie..., op. cit., 143-157. 
podstawowe zaufane; głos sumienia; głębia miłości; pragnienie sensu; sztuka i kultura oraz źródłowe ukierunkowanie ludzkiego życia ${ }^{23}$. Te osobowe doświadczenia pozostają świadectwem, że człowiek ze swej natury pozostaje istotą otwartą na Boga (homo capax Dei), dlatego może przyjąć Objawienie, z którym przychodzi do niego Stwórca.

\section{NURT HISTORYCZNY}

Kwestia obrony historyczności chrześcijaństwa jest ważna przynajmniej z kilku powodów.

Po pierwsze, współcześni apologeci, odpierając zarzuty zwolenników tezy o nietrwałym i tymczasowym charakterze wspólnoty Jezusa, która według nich była raczej ruchem spontanicznym i charyzmatycznym niż grupą, z którą łączyć należy genezę Kościoła, wskazują na istniejącą ciągłość między Chrystusem, głoszonym przez Niego królestwem i pierwotnym chrześcijaństwem. Ich zdaniem, geneza Kościoła należy widzieć w całym życiu Jezusa, który podejmował wyraźne akty eklezjotwórcze (są nimi: zrealizowanie przez Jezusa obietnic dotyczących ludu Bożego zawartych w Starym Testamencie; wezwanie do nawrócenia i wiary w Niego adresowane do wszystkich; ustanowienie Dwunastu jako szczególnej wspólnoty; wybór Piotra i nadanie mu misji; odrzucenia Jezusa przez przywódców żydowskich; ustanowienie Eucharystii; odnowienie przez Chrystusa w fakcie zmartwychwstania swojej wspólnoty z uczniami; zesłanie Ducha Świętego, które staje się proklamacją istnienia Kościoła; wyjście uczniów do pogan i formowanie się wśród nich Kościoła). Chrystus od początku dążył do stworzenia wspólnoty. Ustanawiając Dwunastu, przekazał im władzę. Dzieje Apostolskie, a także wczesna Tradycja pozostają świadectwem stopniowego kształtowania się Kościoła. Jego źródło należy jednak zawsze widzieć w działalności samego Jezusa.

Po drugie, badania historyczne wskazują na realność chrześcijaństwa. Ma ono swój konkretny początek, co potwierdzają nie tylko

${ }^{23}$ H. Seweryniak, Teologia fundamentalna, t. I, 105-116. 
why the attempt to read humanity only in the horizontal dimension becomes a failure. It is impossible to close human life in visible space. The vertical direction gives humanity a deeper dimension. Human existence, according to Seweryniak, has many signs of selftranscendence. These are the desire for happiness, truth and being; amazement at the miracle of existence; the basic trust; the voice of conscience; the depth of love; the desire for meaning; art and culture and the source orientation of human life. These personal experiences remain a testimony that man, by his nature, remains a being open to God (homo capax Dei) and therefore can accept the Revelation with which the Creator comes to him.

\section{HISTORICAL STREAM}

The issue of defending the historicity of Christianity is important for at least several reasons.

First of all, contemporary apologists, in refuting the accusations of supporters of the thesis of the impermanent and temporary character of the community of Jesus, which, in their opinion, was more of a spontaneous and charismatic movement than a group with which the genesis of the Church should be linked, point to the existing continuity between Christ, his proclaimed kingdom and the original Christianity. In their opinion, the genesis of the Church should be seen in the whole life of Jesus, who undertook clear ecclesial acts (they are: Jesus' fulfilment of the promises concerning God's people in the Old Testament; the call to conversion and faith in him addressed to all; the establishment of the Twelve as a special community; the election of Peter and his mission; the rejection of Jesus by Jewish leaders; the establishment of the Eucharist; Christ's renewal in the fact of the resurrection of his fellowship with his disciples; the sending of the Holy Spirit, which becomes the proclamation of the existence of the Church; the departure of disciples to the Gentiles and the formation of the Church among them). From the beginning Christ sought to create community. By establishing the Twelve, he gave them power. The Acts of the Apostles, as well as the early Tradition, remain a 
źródła chrześcijańskie. Nie zrodziło się, jak chcieliby oświeceniowi myśliciele, w umysłach uczniów, którzy przeżywszy traumę odejścia Mistrza, stworzyli Jego mit i pielęgnowali wspomnienia. O realności Kościoła decydują fakty historyczne, które odczytać można z wczesnych źródeł. Proces rekonstrukcji zarówno życia Jezusa, jak i początków Kościoła jednoznacznie pokazuje, że kluczem do przyjęcia wiary dzisiaj, jest realność, historyczność wydarzeń. Apologeci dobrze o tym wiedzą, dlatego w swoich pracach chętnie wracają do genezy Kościoła, która zdaniem krytyków chrześcijaństwa świadczy o fałszerstwie uczniów Jezusa, a także wskazuje na brak wymiaru nadprzyrodzonego obecnego w życiu Jezusa.

Po trzecie, wykazanie historyczności Kościoła poprzez odwołanie się do jego wczesnej tradycji jest szczególnie istotne. Współczesna krytyka chrześcijaństwa jest w gruncie rzeczy kalką oświeceniowych tez. Przy obronie nie wystarczy jednak zastosowanie klasycznej argumentacji apologetycznej. Raczej należy sięgnąć do wszystkich możliwych argumentów, które obalą kłamliwe tezy. Tak czyni chociażby P. Lisicki w pracy poświęconej grobowi św. Piotra ${ }^{24}$. Książka jest uzasadnieniem historyczności prymatu biskupa Rzymu, a zatem obroną samego Kościoła. Kwestia grobu św. Piotra skupia w sobie, jak w soczewce, wątpliwości zarówno liberalnych badaczy, jak i ostrożnych katolików, którzy zamiast bronić świętych relikwii, wolą poddać się sceptycznej retoryce. P. Lisicki postanawia zatem zmierzyć się z tym tematem, bo ma świadomość, że grób galilejskiego rybaka to sprawa fundamentalna dla Kościoła.

\section{NURT CHRYSTOLOGICZNY (TEOLOGICZNY)}

Współcześni apologeci podejmują obronę Jezusa „środkami i słowami dziennikarskimi" ${ }^{25}$, towarzyszy im jedna wyraźne zacięcie

${ }^{24}$ P. Lisicki, Grób rybaka. Śledztwo w sprawie największej tajemnicy watykańskich podziemi, Warszawa 2019.

${ }_{25}$ V. Messori, Opinie o Jezusie. „A wy za kogo mnie uważacie?”, przekład T. Jania, Kraków 1994,8. 
testament to the gradual formation of the Church. Its source, however, should always be seen in the activity of Jesus himself.

Secondly, historical research indicates the realness of Christianity. It has its own beginning, which is confirmed not only by Christian sources. It was not born, as the enlightened thinkers would have it, in the minds of disciples who, having experienced the trauma of the Master's passing away, created His myth and nurtured memories. The realness of the Church is determined by historical facts, which can be read from early sources. The process of reconstruction of both the life of Jesus and the beginnings of the Church shows unequivocally that the key to the acceptance of faith today is the reality, the historicity of events. The apologists know this well, which is why in their works they are eager to return to the origins of the Church, which, according to critics of Christianity, testifies to the falsification of Jesus' disciples, and also points to the lack of the supernatural dimension present in Jesus' life.

Thirdly, it is particularly important to demonstrate the Church's historicity by referring to its early tradition. Contemporary criticism of Christianity is, in fact, a cripple of Enlightenment theses. In defence, however, it is not enough to use classic apologetic arguments. Rather, all possible arguments should be used to disprove false theses. So does Lisicki in his work on St Peter's tomb ${ }^{23}$. The book justifies the historical primacy of the Bishop of Rome and therefore defends the Church itself. The issue of the tomb of St Peter focuses, as in the lens, the doubts of both liberal researchers and cautious Catholics who, instead of defending holy relics, prefer to submit to sceptical rhetoric. Lisicki therefore decides to address this subject, since he is aware that the grave of the fisherman from Galilee is a fundamental matter for the Church.

${ }^{23}$ Lisicki, P. (2019) Grób rybaka. Śledztwo w sprawie największej tajemnicy watykańskich podziemi, Warsaw. 
naukowe ${ }^{26}$. V. Messori tę procedurę nazywa „okradaniem profesorów”; „cytując ich oczywiście, wyznaje, jestem im wdzięczny, ponieważ bez ich pracy, także moja praca nie byłaby możliwa, nigdy jednak nie chciałem zająć miejsca na katedrze"27. Włoski dziennikarz celowość tej apologii uzasadnia w następujący sposób: „,co do Jezusa wypowiedziano już wszelkie możliwe hipotezy, (...) zarzuty zostały już obalone, potem na nowo powstały, znów je odrzucono, i tak w nieskończoność" 28 . Jednak od czasów oświecenia „kwestionuje się to, co dotąd było faktem ustalonym nawet w najbardziej ostrej i agresywnej polemice. Chodziło o wiarę w szczególny związek pomiędzy człowiekiem a Jezusem i Bogiem, o uznanie Go za Chrystusa, za oczekiwanego przez Izrael Mesjasza"29. Współczesna apologia Jezusa, koncentrując się na wykazaniu historyczności Jezusa oraz uzasadnieniu Jego boskości, obejmuje przynajmniej kilka wymiarów. M. Hesemann i P. Badde badają odkrycia archeologiczne. A. Socci zmaga się z zarzutami ideologicznymi, a P. Lisicki, broniąc osoby Jezusa, dostarcza argumentów historyczno-teologicznych.

M. Hesemann ${ }^{30}$ i P. Badde ${ }^{31}$, przemierzając Ziemię Świętą, szukają w niej śladów historycznego Jezusa. Przyjmują następującą procedurę. Najpierw zapoznają się z tekstami Ewangelii, one stają się przewodnikiem w podróży, następnie tworzą możliwie najpełniejsze kompendium na temat poszczególnych zabytków archeologicznych. Dane biblijne porównują z wynikami badań archeologów. Wykorzystują przy tym literaturę starożytną, zarówno pogańską, jak i żydowską, relacje zapisane w pielgrzymkowych itinerariach oraz wszelkie wzmianki znajdujące się u pisarzy wczesnochrześcijańskich.

${ }^{26}$ Cf. V. Messori, Dlaczego wierzę? Życie jako dowód wiary, przekład M. Wójcik, Kraków 2009, 325.

27 Ibidem, 326.

28 V. Messori, Opinie..., 13.

29 Ibidem, 13-14.

${ }^{30}$ Cf. M. Hesemann, Na tropie Jezusa z Nazaretu. Ziemia Zbawiciela, przekład P. Kolińska, Kraków 2012.

${ }^{31}$ Cf. P. Badde, Ziemia Boga w 20 tajemnicach, przekład M. Masny, Bytom 2013. 


\section{CHRISTOLOGICAL (THEOLOGICAL) STREAM}

Today's apologists take up Jesus' defence with, journalistic means and words ${ }^{24}$, accompanied by one clear scientific verve ${ }^{25}$. Messori calls this procedure ,robbing professors'; whilst, to quote them, of course, he confesses, I am grateful to them, because without their work, my work would not have been possible either, but I never wanted to take my place in the cathedral ${ }^{26}$. An Italian journalist justifies this apologia as follows: „', 'as for Jesus, all possible hypotheses have already been expressed, (...) the allegations have already been rebutted, then reopened, rejected again, and so on forever' ${ }^{27}$. However, since the Enlightenment, what was previously an established fact even in the most harsh and aggressive polemics is called into question. It was about believing in the special relationship between man and Jesus and God, about recognizing him as Christ, as the Messiah awaited by Israel ${ }^{\prime 28}$. The contemporary apologia of Jesus, focusing on demonstrating the historical nature of Jesus and justifying his divinity, covers at least several dimensions. Hesemann and Badde explore archaeological discoveries. Socci struggles with ideological accusations, while Lisicki, defending the person of Jesus, provides historical and theological arguments.

Hesemann $^{29}$ i Badde ${ }^{30}$, wandering through the Holy Land, look for traces of the historical Jesus. They adopt the following procedure. First they become familiar with the texts of the Gospel, which become a guide on the journey, then they create the most complete compendium on individual archaeological sites. They compare biblical data with the

24 Messori, V. (1977) Jesus Hypotheses

${ }_{25}$ See Messori, V. (2009) Why I believe? Life as Proof of Faith

${ }^{26}$ Ibidem, 326.

27 V. Messori, Jesus Hypotheses

28 Ibidem, 13-14.

29 See Hesemann, M. Jesus von Nazareth: Archäologen auf den Spuren des Erlösers, Polish translation by Kolińska, P. (2012) Kraków.

${ }^{30}$ See Badde, P. Earth of God in 20 Mysteries, Polish translation by Masny, M. Bytom 2013. 
Stworzona przez apologetów argumentacja archeologiczna zawiera bezpośrednie poświadczenie wiarygodności ewangelicznych przekazów. Dziennikarze rozpoznają zgodność Jezusa z kontekstem judaistycznym, a równocześnie dostrzegają Jego odmienność w obrębie religii żydowskiej. Odtwarzając dzieje pierwotnego Kościoła, wskazują na ciągłość między Chrystusem i wspólnotą uczniów a późniejszymi chrześcijanami, w działaniach Rzymian I oraz II w. dostrzegają elementy substytucji pogańskiej.

A. Socci ${ }^{32}$, podejmując apologię Jezusa, stawia sobie za cel odparcie zarzutów ideologicznych. Wypracowuje w ten sposób argumentację antyideologiczną. Opiera się ona w głównej mierze na analizie źródeł dotyczących historyczności Jezusa oraz ukazaniu racji świadczących o Jego boskiej tożsamości. Włoski dziennikarz dowartościowuje rolę świadków w procesie formowania się Ewangelii oraz znacznie poszerza zbiór źródeł pogańskich poświadczających historyczność Jezusa. O ile kwestię naocznego świadectwa należy ocenić pozytywnie, o tyle do analizy źródeł niechrześcijańskich należy odnieść się krytycznie. A. Socci prezentuje je zbyt jednostronnie (zgodnie z przyjętym założeniem), powołując się na dokumenty, czy też odkrycia archeologiczne wątpliwe lub trudne do jednoznacznego określenia. Czyni to, aby uzasadnić tezę o życzliwej relacji władz rzymskich do Jezusa i chrześcijaństwa, która cechowała cesarzy aż do panowania Nerona. Obok nich analizowane są również źródła klasyczne, nie zawsze jednak zgodnie z intencjami autorów. Włoski dziennikarz także w przypadku tych dokumentów dokonuje nadinterpretacji.

P. Lisicki ${ }^{33}$, podejmując apologię Jezusa, wypracowuje argumentację historyczno-teologiczną. Szukając odpowiedzi na pytanie, kto

${ }^{32}$ Cf. A. Socci, Śledztwo w sprawie Jezusa, przekład K. Kubis, Kraków 2010; A. Socci, Wojna przeciwko Jezusowi, przekład A. Gogolin, Kraków 2012.

${ }^{33}$ Cf. P. Lisicki, Kto zabił Jezusa? Prawda i interpretacja, Kraków 2013; P. Lisicki, Tajemnica Marii Magdaleny. Fakty i mity, Kraków 2014; P. Lisicki, Czy Jezus jest Bogiem? Od judaizmu do chrześcijaństwa, Kraków 2014; P. Lisicki, Dżihad i samozagłada Zachodu, Lublin 2015; P. Lisicki, Krew na naszych rękach. Religia Holocaustu i tożsamość Europy, Lublin 2016; P. Lisicki, Poza polityczna 
results of archaeological research. They exploit ancient literature, both pagan and Jewish, the accounts recorded in the pilgrimage itineraries and any mentions made by early Christian writers. The archaeological argumentation created by the apologists contains a direct statement of credibility of the evangelical messages. Journalists recognise the conformity of Jesus with the Judaic context and at the same time recognise his difference within the Jewish religion. Reconstructing the history of the original Church, they point to the continuity between Christ and the community of disciples and later Christians, and they see elements of Gentile substitution in the actions of Romans of the first and second centuries.

By taking up Jesus' apologia, Socci ${ }^{31}$, aims to repel ideological accusations. In this way he develops an anti-ideological argumentation, which is based mainly on an analysis of the sources concerning the historicity of Jesus and showing the reasons that prove his divine identity. The Italian journalist values the role of witnesses in the process of the formation of the Gospel and significantly expands the collection of pagan sources testifying to the historicity of Jesus. While the question of eyewitness should be assessed positively, the analysis of non-Christian sources should be criticised. Socci Socci presents them too unilaterally (according to the adopted assumption), citing documents or archaeological discoveries that are doubtful or difficult to define clearly. He does so in order to justify the the thesis about the benevolent relationship of the Roman authorities to Jesus and Christianity, which characterised the emperors until the reign of Nero. In addition to these, classical sources are also analysed, but not always according to the intentions of the authors. In the case of these documents, too, an Italian journalist overinterprets.

${ }^{31}$ See Socci, A. The Case for Christ: A Journalist's Personal Investigation of the Evidence for Jesus, Polish translation by Kubis, K. Kraków 2010; A. Socci, The War against Jesus, Polish translation by Gogolin, A. Kraków 2012. 
zabił Jezusa, rekonstruuje najpierw wydarzenia pasyjne. Szczegółowo odtwarza ostatnie dni Chrystusa w szerokiej perspektywie historycznej. Wykazuje się przy tym doskonałą znajomością literatury przedmiotu, jak i interpretacją źródeł. Tytułowe pytanie staje się przyczyną rozbudowanej narracji, która służy uzasadnieniu historyczności Jezusa. Poszukiwania teologiczne, znamionuje z kolei pytanie o moment narodzin kultu Jezusa. Wypracowując uzasadnienie boskości, P. Lisicki analizuje najpierw koncepcje krytyczne. Zwraca przy tym uwagę na obecne w nich błędne założenia i co za tym idzie chybione wnioski. Następnie prezentuje myśl współczesnych biblistów, odtwarzających proces narodzin kultu Jezusa. W końcu wypracowuje własną argumentację, ukazując autorską koncepcję deifikacji Mistrza z Nazaretu.

\section{NURT KONTEKSTUALNY}

Nowa apologia ma pełną świadomość historyczno-społecznego kontekstu. Chrześcijaństwo, zanurzone w ziemskiej rzeczywistości, doświadcza jej zmienności, wyłaniania się nowych prądów, staje także przed różnorodnymi wyzwaniami. Co zatem tworzy współczesny kontekst wiary? Z jakimi zjawiskami spotkają się apologeci, jakim prądom muszą stawić czoła? Zwrócę uwagę zaledwie na dwa charakterystyczne pojęcia, kształtujące współczesny kontekst chrześcijaństwa.

Pierwszy termin, to alethofobia. Kryje się za nim wyjątkowo niebezpieczna ideologia. G. Vattimo, czołowy filozof postmodernistyczny, jedną ze swoich książek zatytułował „Addio alla verità”, czyli „Pożegnanie z prawdą”. Uzasadniał w niej, że prawda transcendentna nie istnieje. O. M. Zięba dodaje, że ta ponowoczesna idea, „choć nie jest dowiedziona naukowo (bo być nie może) i jest arbitralnie dokonanym wyborem, staje się norma normans non normata - uzyskuje

poprawnością. Polska, Europa i Kościót między nihilizmem a islamem, Kraków 2017. 
On the other hand, Lisicki ${ }^{32}$, when taking up Jesus' apologia, develops a historical and theological argumentation. In search of an answer to the question of who killed Jesus, he first reconstructs the Passionate events. He recreates in detail the last days of Christ in a broad historical perspective. He shows an excellent knowledge of the literature on the subject, as well as an interpretation of sources. The headline question becomes the cause of an elaborate narrative which serves to justify the historicity of Jesus. The theological search, in turn, marks the question of the moment of the origin of the cult of Jesus. Working out the justification of the divinity, Lisicki first analyses the critical concepts, drawing attention to the erroneous assumptions present therein and, consequently, wrong conclusions. Next, he presents the thought of contemporary biblicalists, recreating the origin of the cult of Jesus. Finally, he develops his own argumentation, showing the author's concept of deification of the Master of Nazareth.

\section{CONTEXTUAL STREAM}

The new apologia bears full awareness of the historical and social context. Christianity, immersed in earthly reality, experiences its changeability, new currents emerge and faces various challenges. So what creates the contemporary context of faith? What phenomena will apologists encounter, what currents do they have to face? The author draws the reader's attention to just two characteristic concepts that shape the contemporary context of Christianity.

The first term is alethophobia, which relates to an extremely dangerous ideology. Vattimo, a leading postmodern philosopher, entitled one of his books „Addio alla verità", or „Farewell to the truth”.

${ }^{32}$ See Lisicki, P. Kto zabił Jezusa? Prawda i interpretacja, Kraków 2013; Lisicki, P. Tajemnica Marii Magdaleny. Fakty i mity, Kraków 2014; Lisicki, P. Czy Jezus jest Bogiem? Od judaizmu do chrześcijaństwa, Kraków 2014; Lisicki, P. Dżihad i samozagłada Zachodu, Lublin 2015; Lisicki, P. Krew na naszych rękach. Religia Holocaustu i tożsamość Europy, Lublin 2016; Lisicki, P. Poza polityczna poprawnością. Polska, Europa i Kościół między nihilizmem a islamem, Kraków 2017. 
współcześnie status prawdy objawionej" ${ }^{34}$. W twierdzeniu tym tkwi ogromne niebezpieczeństwo. Jeżeli bowiem wierzę, że „«wiem, iż nie ma prawdy absolutnej», to zarazem wierzę, że nie ma wartości transcendentnych, a zatem każdy, kto sądzi inaczej, jest uzurpatorem"35. Akceptacja tego rodzaju przekonań, pociąga za sobą konkretne decyzje. Są nimi nie tylko prześladowania i terror, u źródeł których tkwi nietolerancja, lecz także imperatyw „oczyścić życie publiczne z odniesień do tradycyjnych, absolutnych wartości”"36 i promowanie instytucji, „które uczą relatywizmu kulturowego"37. M. Zięba celnie zauważa, że w tej perspektywie ponowoczesna teza, zamienia się w jakąś nową wersję liberalizmu i spełnia wszystkie kryteria ideologii. Ma bowiem sprecyzowaną koncepcję prawdy: „nie ma prawdy absolutnej"38. Chce własny projekt życia narzucić innym i wie, jak to zrobić. Podstawowymi wartościami tej ideologii są: kulturowy relatywizm, negujący istnienie prawdy i wartości transcendentnych oraz skrajny indywidualizm, pozostający konsekwencją kluczowej definicji: skoro nie ma prawdy absolutnej, każdy może być twórcą prawdy i jest to jego prawda, do której ma pełne prawo. M. Zięba, tego rodzaju pogląd, który jest ideologiczną formą postmodernistycznego liberalizmu, eliminującego z publicznego dyskursu kwestię prawdy transcendentnej, nazywa alethofobia. Zdaniem dominikanina, jest to ideologia nowego typu, przybierająca postać hybrydową: ,nie ma bowiem jednego ośrodka decyzyjnego lub tekstów ją konstytuujących, używa ona zarówno starszych oświeceniowych klisz i stereotypów, jak i najnowszych wyników badań społecznych oraz humanistycznych (które sama w znacznej mierze kształtuje), stosuje strategie cząstkowe (np. political correctness), a mimo zapewnień o tolerancji jest wroga wobec zorganizowanych form religii, przy czym stosuje

${ }^{34}$ M. Zięba, Od pacyfizmu do świętej wojny, czyli 10 tez o religii i przemocy, w: M. Zięba, Kłopot..., op. cit., 180-181.

35 Ibidem, 181.

36 Ibidem.

37 Ibidem.

38 Ibidem. 
There he justifies that transcendent truth does not exist. Fr. Zięba adds that this postmodern idea, ,although it is not scientifically proven (because it cannot be) and is an arbitrary choice, becomes norma normans non normata - it acquires the status of revealed truth today". ${ }^{33}$ There is a great danger in this statement. For if I believe that ,I know that there is no absolute truth', then I also believe that there are no transcendent values, so anyone who thinks otherwise is a usurper'. ${ }^{34}$ Acceptance of such beliefs entails particular decisions. These are not only persecution and terror, at the root of which lies intolerance, but also the imperative of ,clearing public life of references to traditional, absolute values ${ }^{35}$ and promoting institutions, that teach cultural relativism. ${ }^{36}$ Zięba accurately observes that in this perspective, the post-modern thesis turns into some new version of liberalism and meets all the criteria of ideology. For it has a precise concept of truth which says ,there is no absolute truth". ${ }^{37} \mathrm{He}$ wants to impose his own life project on others and knows how to do it. The basic values of this ideology are cultural relativism, which denies the existence of truth and transcendent values, and extreme individualism, which is the consequence of a key definition: since there is no absolute truth, everyone can be the creator of truth and this is their truth, to which they are fully entitled. Zięba calls this kind of view, which is an ideological form of post-modern liberalism, eliminating the issue of transcendent truth from public discourse, alethophobia. According to this Dominican, it is a new type of ideology, taking on a hybrid form, „for there is no single decision-making centre or the texts that constitute it, it uses both older Enlightenment clichés and stereotypes, as well as the latest results of social and humanist research (which it itself largely shapes), it uses partial strategies (e.g.

33 Zięba, M. Od pacyfizmu do świętej wojny, czyli 10 tez o religii i przemocy, in: Zięba, M. Kłopot..., op. cit., 180-181.

${ }^{34}$ Ibidem, 181.

35 Ibidem.

36 Ibidem.

${ }^{37}$ Ibidem. 
zróżnicowaną taktykę - znacznie bardziej okazuje swą wrogość wobec chrześcijaństwa (zwłaszcza katolicyzmu) niż wobec islamu, judaizmu czy religii Dalekiego Wschodu"39. Celem zwolenników tej ideologii jest stworzenie nowego człowieka, wolnego od tradycyjnych więzi.

Multikulturalizm z kolei, to jeden z kluczowych terminów dla współczesnego świata, robiący dzisiaj zawrotną karierę ${ }^{40}$. Nie oznacza on jedynie istnienia obok siebie różnorodnych kultur, które mieszają się, nakładają na siebie czy egzystują równolegle. W słowie tym nie chodzi również o wielość tradycji spotykających się ze sobą w zglobalizowanej rzeczywistości. Posługując się tym terminem, dotykamy rzeczywistości głęboko zideologizowanej, której daleko do chrześcijańskich korzeni. Multikulturalizm, będąc dzisiaj religią polityczną, zgłasza aspiracje do przemiany zachodniej cywilizacji, przybierające niejednokrotnie radykalne formy. Jako ideologia narodził się w roku 1968 i od razu stał się wiodącym hasłem nowej lewicy. Tego pojęcia uczepili jej zwolennicy, dostrzegając powolny zmierzch tradycyjnego, a zatem rewolucyjnego marksizmu. Koncept Marksa przestał być już atrakcyjny. Stał się niewiarygodny jako teoria. Nie tłumaczył zachodzących przemian społecznych, nie rozumiał ich. Lewicowi intelektualiści, przejmując rząd dusz w latach sześćdziesiątych XX w., intensywnie poszukiwali nowego podmiotu rewolucyjnego. Ich wzrok padł na formy wykluczenia społecznego. „Zamiast robotnikiem, zaczęto interesować się wykluczonymi. Ta ostatnia kategoria miała obejmować tych, którzy sytuują się na zewnątrz, poza systemami normatywnymi obowiązującymi na Zachodzie"41. Nowa lewica, rozpoczynająca swój marsz po władzę, porzuciła krytykę kapitalizmu na rzecz krytyki cywilizacji zachodniej. Na jej celowniku znalazły się instytucje uznawane za strażników tradycyjnych wartości, a więc Kościół, państwo, naród, rodzina, szkoła. Różnorodność

39 Ibidem, 182.

40 Cf. H. Seweryniak, Apologia i..., op. cit., 315-324.

${ }^{41}$ M. Bock-Côté, Multikulturalizm jako religia polityczna, przekład M. Chojnacki, Warszawa 2016, 14. 
political correctness), and despite assurances of tolerance, it is hostile to organised forms of religion, and it uses varied tactics - it is much more hostile to Christianity (especially Catholicism) than to Islam, Judaism or Far Eastern religions". ${ }^{38}$ The supporters of this ideology aim to create a new man, free from traditional ties.

Multi-culturalism, in turn, is one of the key terms for the modern world, making a stunning career today. ${ }^{39}$ It does not just mean that there are different cultures that mix, overlap or exist in parallel. Nor does it mean the multiplicity of traditions that meet each other in a globalised reality. By using this term, we are touching upon a deeply ideologised reality that is far from its Christian roots. Multiculturalism, being a political religion today, expresses aspirations for the transformation of Western civilisation, which often take on radical forms. As an ideology, it was born in 1968 and immediately became the leading slogan of the new Left Wing. Its supporters firmly established this notion, recognising a slow decline in traditional and therefore revolutionary Marxism. The concept of Marx was no longer attractive and became obsolete and unreliable as a theory. It has become unreliable as a theory. It did not explain the social changes taking place, nor did it understand them. Left-wing intellectuals, taking over the government of souls in the 1960s, were intensively searching for a new revolutionary subject. What they spotted was forms of social exclusion. „Instead of a worker, they began to take an interest in the excluded. The latter category was to include those who were outside, beyond the normative systems of the West". ${ }^{40}$ The new Left Wing, beginning its march for power, abandoned criticism of capitalism in favour of criticism of Western civilisation. It targeted institutions regarded as guardians of traditional values, i.e. the Church, state, nation, family, and school. The left-wingers treated diversity as the flywheel of history, claiming that it is the greatest

38 Ibidem, 182.

39 See Seweryniak, H. Apologia i..., op. cit., 315-324.

40 Bock-Côté, M. „Multiculturalism as a Political Religion”, Le Débat, vol. no. 186, no. 4, 2015, 122-136, Polish translation by M. Chojnacki, Warsaw 2016, 14. 
lewacy potraktowali jako koło zamachowe historii, głosząc, iż jest ona największym bogactwem. Pojęcie to stało się hasłem globalnej transformacji i wezwaniem do dokonania redefinicji najważniejszych pojęć, a także głównym składnikiem ideologii multikulturalizmu. Różnorodność w nowolewicowej perspektywie to „skojarzenie ze sobą różnych roszczeń tożsamościowych i społecznych"42, które wyłoniły się na fali kontestacji lat sześćdziesiątych. Program zaś tej multikulturowej ideologii jest następujący: krytyka zachodniej cywilizacji, dekonstrukcja tradycji, wymyślenie antyrasizmu, zagarnięcie demokracji przez mniejszość, kult praw człowieka, ideologia antydyskryminacji, prymat prawa nad polityką. To tylko niektóre postulaty nowego autorytaryzmu, który skrywa się pod niewinnie brzmiącym pojęciem wielokulturowości.

\section{NURT TEISTYCZNY}

Apologeci tego nurtu, broniąc Boga, zmagają się przede wszystkim z nowym ateizmem ${ }^{43}$. Terminu tego użył jako pierwszy G. Wolf, publikując w roku 2006 na łamach angielskiego magazynu „Wired” artykuł o trzech głośnych książkach antyreligijnych. Były nimi: „Koniec wiary” Sama Harrisa, „Odczarowanie. Religia jako zjawisko naturalne” Daniela Dennetta oraz „Bóg urojony” Richarda Dawkinsa. Z czasem do tego grona dołączono Christophera Hitchensa, który - publikując pracę „Bóg nie jest wielki” - stał się czwartym ideologiem nowego ateizmu, wyraźnie różniącego się od klasycznych form negacji. Jego specyfika nie dotyczy jedynie nazwy. Z pewnością jest bardziej agresywny, nie przebiera w środkach, wszystko dla niego jest dobre, co służy ośmieszeniu religii i ludzi wierzących.

${ }^{42}$ Ibidem, 15.

${ }^{43} \mathrm{Na}$ temat nowego ateizmu, cf. Czterej jeźdźcy apokalipsy. Jak zaczęła się ateistyczna rewolucja?, przekład P.J. Szwajcer, Warszawa 2019; J. Guja, Soteriologia ateizmu jako nowa antropologia, Kraków 2018; T. Sieczkowski, Nowy ateizm. Rekonstrukcja światopogladu, Łódź 2018; R. Rożdżeński, Ateizm, czyli wiara negatywna. Ateistyczne przeświadczenia z perspektywy pytań granicznych, Kraków 2016. 
wealth. This concept became a slogan of global transformation and a call for a redefinition of the most important concepts, as well as a major component of the ideology of multiculturalism. which emerged upon a wave of protest in the 1960s. The programme of this multicultural ideology is as follows: criticism of Western civilisation, deconstruction of traditions, the invention of anti-racism, the seizure of democracy by a minority, the cult of human rights, the ideology of anti-discrimination, and the primacy of law over politics. These are just some of the demands of the new authoritarianism, which hides under the innocent-sounding concept of multiculturalism.

\section{THEISTIC STREAM}

While defending God, Apologists of this trend struggle with the new atheism in particular. ${ }^{41}$ Wolf was the first to use this term when he published an article on three famous anti-religious books in the English magazine Wired in 2006. Those were: The End of Faith by Sam Harris, Disenchantment. Religion as a Natural Phenomenon by Daniel Dennett and The God Delusion by Richard Dawkins. In time, Christopher Hitchens with his work God is Not Great was added to the group, and became the fourth ideologist of the new atheism, clearly different from the classical forms of negation. Its specificity is not only about the name. He is certainly more aggressive and unscrupulous, and anything which serves to ridicule religion and the believers is good for him. The new atheism instrumentalises the natural sciences for its purposes, manipulates research results and thus tries to impose its own view of the world. The German

${ }^{41}$ On new atheism, see Czterej jeźdźcy apokalipsy. Jak zaczęta się ateistyczna rewolucja?, Polish translation by P.J. Szwajcer, Warsaw 2019; Guja, J. Soteriologia ateizmu jako nowa antropologia, Kraków 2018; Sieczkowski, T. Nowy ateizm. Rekonstrukcja światopogladu, Łódź 2018; Rożdżeński, R. Ateizm, czyli wiara negatywna. Ateistyczne przeświadczenia z perspektywy pytań granicznych, Kraków 2016. 
Nowy ateizm instrumentalizuje dla swoich celów nauki przyrodnicze, manipuluje wynikami badań i w ten sposób próbuje narzucić swój własny pogląd na świat. Znakomicie uchwycił działania nowych ateistów niemiecki teolog G. Lohfink ${ }^{44}$. Niczym misjonarze, „naukowcy, publicznie głoszący ateizm, piszą książki - stające się szybko bestsellerami - skierowane przeciw chrześcijaństwu. Mają oni wiele do powiedzenia w telewizji. Wszędzie propagują swoją teorię świata i domagają się na cały głos, aby ona stała się panująca. Oni też rezerwują tylko i wyłącznie dla siebie prawo tłumaczenia całej rzeczywistości. Przemysł, zorganizowany wokół kultury, sięga chciwie po ich argumenty. Ma wielki żołądek. Cały czas potrzebuje pożywki. Łaknie również takiego tematu jak «ateizm»"45. Jaki cel stawiają sobie nowi ateiści? Chodzi im przede wszystkim o wyrugowanie ze świata „niebezpiecznej głupoty”, jaką jest religia. Czynią to w imię nauki i humanizmu. W tym celu organizują się w związki i systematycznie podejmują walkę z religijnymi zabobonami. Przedstawiają przy tym religię jako truciznę, ,która zawsze wnosiła do świata gwałt, terror i zniewolenie" ${ }^{\star 46}$. Zdaniem nowych ateistów, „,kto wierzy w Boga, ten nie tylko jest w błędzie, ale jest też zaślepiony i cierpi urojenia" ${ }^{97}$. Wierzący stanowią dla społeczeństwa bardzo niebezpieczną kategorię, dlatego „koniecznie potrzebują pomocy, która wyzwoli ich z narzuconych przez wiarę zachowań"48. Jakimi argumentami posługują się nowi ateiści? W zasadzie wykorzystują

${ }^{44}$ Apologia wobec nowego ateizmu, cf. P. Bloch, Urojony Bóg Richarda Dawkinsa, Warszawa 2011; D.B. Hart, Chrześcijańska rewolucja a złudzenie ateizmu, przekład A. Gomola, Kraków 2011; A. McGrath, Bóg Dawkinsa. Geny, memy i sens życia, przekład J. Gilewicz, Kraków 2008; T. Pabjan, Anatomia konfliktu. Między nowym ateizmem a teologia nauki, Kraków 2016; Wiederkehr des Atheismus. Fluch oder Segen für die Theologie?, red. M. Striet, Freiburg im Breisgau 2008; Wobec nowego ateizmu, red. I. Bokwa, M. Jagodziński, Warszawa 2011.

${ }_{45}$ G. Lohfink, Jakie argumenty ma nowy ateizm? Krytyczna dyskusja, przekład J. Machnacz, Wrocław 2009, 17.

46 Ibidem, 18.

${ }^{47}$ Ibidem, 19.

48 Ibidem. 
theologian Lohfink perfectly captured the actions of the new atheists..$^{42}$ Like missionaries, ,scientists, who publicly proclaim atheism, write books - soon to become bestsellers - directed against Christianity. They have much to say on television. They promote their theory of the world everywhere, and they demand it out loud and clear that it should prevail. They, too, reserve the right to translate the whole reality for themselves. The industry, organised around culture, greedily reaches for their arguments. It has a big stomach which needs constant feeding. It also craves for a subject like «atheism». ${ }^{43}$ What is the new atheists' purpose? They are primarily concerned with getting the ,dangerous stupidity' of religion out of the world. They pursue this in the name of science and humanism. Therefore, they form associations and systematically fight against religious superstitions. In doing so, they present religion as a poison, ,which has always brought rape, terror and enslavement to the world'.$^{44} \mathrm{Zdaniem}$ nowych ateistów, „kto wierzy w Boga, ten nie tylko jest w błędzie, ale jest też zaślepiony i cierpi urojenia" ${ }^{{ }^{4} 5}$. Believers are a very dangerous category for society, and therefore, they absolutely need help to free them from behaviour imposed by faith'. ${ }^{46}$ What are the arguments used by the new atheists? Basically, they use old slogans, heated by evolutionary biology. God is a projection to them; man is the result of evolution; suffering denies the existence of God; religions only

${ }^{42}$ Apologia vs. new atheism, see Bloch, P. Richard Dawkins' God Delusion, Warsaw 2011; Hart, D.B. Atheist Delusions: The Christian Revolution and Its Fashionable Enemies, Polish translation by A. Gomola, Kraków 2011; McGrath, A. Dawkins' GOD: Genes, Memes, and the Meaning of Life, Polish translation by J. Gilewicz, Kraków 2008; Pabjan, T. Anatomia konfliktu. Między nowym ateizmem a teologia nauki, Kraków 2016; Wiederkehr des Atheismus. Fluch oder Segen für die Theologie?, ed. Striet, M. Freiburg im Breisgau 2008; Wobec nowego ateizmu, ed. Bokwa, I. , Jagodziński, M. Warsaw 2011.

${ }^{43}$ G. Lohfink, Welche Argumente hat der neue Atheismus? Eine kritische Auseinandersetzung. Urfeld, Bad Tölz 2008, Polish translation by J. Machnacz, Wrocław 2009, 17.

${ }^{44}$ Ibidem, 18.

${ }^{45}$ Ibidem, 19.

46 Ibidem. 
stare slogany, podgrzewane biologią ewolucyjną. Bóg jest dla nich projekcją; człowiek powstał w wyniku ewolucji; cierpienie przeczy istnieniu Boga; religie generują jedynie przemoc; dobro pochodzi z nas; Biblia jest prymitywna; nie ma innego życia poza ziemią.

\section{Podsumowanie}

Warszawska Szkoła Apologetyczna od końca lat pięćdziesiątych systematycznie podejmowała refleksję nad apologiami zgodnie z własną metodologią. Nawiązując do tych badań, teologowie fundamentalni z UKSW, spadkobiercy warszawskich apologetyków, dostrzegają fenomen nowej apologii. Metodycznie ją analizują, formułując definicję i ukazując związki nowej apologii z apologetyką i teologią fundamentalną. Dostrzegają zarówno obszary zainteresowań współczesnej apologii, jak też różnorodne nurty obecne wśród apologetów. Najważniejsze z nich to obrona człowieka, historyczności chrześcijaństwa, boskości Jezusa Chrystusa, wartości ufundowanych na wierze oraz Boga w zmieniającym się kontekście.

Słowa kluczowe: apologia

\section{Nota o Autorze}

Ks. dr hab., prof. UKSW Przemysław Artemiuk (ur. 1974) - teolog fundamentalny, adiunkt w Katedrze Teologii Fundamentalnej i Prakseologii Apologijnej WT UKSW w Warszawie, wykładowca w Wyższym Seminarium Duchownym w Łomży oraz przewodniczący Stowarzyszenia Teologów Fundamentalnych w Polsce, ostatnio opublikował monografię „W obronie spraw najważniejszych. Szkice o apologii” (2019) oraz zredagował tom studiów „Teologia wobec wyzwań współczesnych nauk o człowieku" (2019).

\section{Bibliografia}

Artemiuk P., Renesans apologii, Płock 2016.

Artemiuk P., W obronie spraw najważniejszych. Szkice o apologii, Poznań 2019.

Badde P., Ziemia Boga w 20 tajemnicach, przekład M. Masny, Bytom 2013.

Bloch P., Urojony Bóg Richarda Dawkinsa, Warszawa 2011. 
generate violence; good comes from us; the Bible is primitive; and last but not least, there is no life after life.

\title{
Summary
}

Since the end of the 1950s, the Warsaw School of Apologia systematically undertook reflection on various apologia according to its own methodology. Referring to this research, fundamental theologians from the UKSW, the heirs of Warsaw apologists, see the phenomenon of a new apologia. They analyse it methodically, formulating a definition and showing the links of the new apologia with apologetics and fundamental theology. They see both the areas of interest of contemporary apologia and the various currents present among apologists. The most important of these are the defence of man, the historicity of Christianity, the divinity of Jesus Christ, values founded on faith and God in a changing context.

Key words: apology

\begin{abstract}
About the Author
Father Przemysław Artemiuk, Ph.D., professor of the UKSW (born 1974) a fundamental theologian, assistant professor in the Department of Fundamental Theology and Apological Praxeology at the University of Warsaw (WT UKSW), lecturer at the Higher Theological Seminary in Lomza and president of the Association of Fundamental Theologians in Poland, has recently published a monograph entitled „In defence of the most important matters. Sketches on apologia” (2019) and edited the volume of the study entitled ,Theology Towards the Challenges of Modern Human Sciences'. (2019)
\end{abstract}


Bock-Côté M., Multikulturalizm jako religia polityczna, przekład M. Chojnacki, Warszawa 2016.

Bronić czy dialogować? O pewnym dylemacie chrześcijaństwa dzisiaj, red. H. Seweryniak, P. Artemiuk, Płock 2016.

Czterej jeźdźcy apokalipsy. Jak zaczęła się ateistyczna rewolucja?, przekład P.J. Szwajcer, Warszawa 2019.

Guja J., Soteriologia ateizmu jako nowa antropologia, Kraków 2018.

Hart D.B., Chrześcijańska rewolucja a złudzenie ateizmu, przekład A. Gomola, Kraków 2011.

Hesemann M., Na tropie Jezusa z Nazaretu. Ziemia Zbawiciela, przekład P. Kolińska, Kraków 2012.

Kwiatkowski W., Apologetyka totalna, t. I, Warszawa 1961.

Kwiatkowski W., Apologetyka totalna, t. II, Warszawa 1962.

Kwiatkowski W., Początki i rozwój Warszawskiej Szkoły Apologetycznej, „Studia Theologica Varsaviensia" 3/1965 nr 1, s. 5-18.

Ledwoń I.S., Apologetyka, w: Leksykon teologii fundamentalnej, red. M. Rusecki, K. Kaucha, I.S. Ledwoń, J. Mastej, Lublin-Kraków 2002, s. 78-85.

Lisicki P., Kto zabił Jezusa? Prawda i interpretacja, Kraków 2013.

Lisicki P., Czy Jezus jest Bogiem? Od judaizmu do chrześcijaństwa, Kraków 2014.

Lisicki P., Tajemnica Marii Magdaleny. Fakty i mity, Kraków 2014.

Lisicki P., Wstęp, w: Gender. Kontrrewolucja, Kraków 2014, s. 5-8.

Lisicki P., Dżihad i samozagłada Zachodu, Lublin 2015.

Lisicki P., Krew na naszych rękach. Religia Holocaustu i tożsamość Europy, Lublin 2016.

Lisicki P., Poza polityczną poprawnością. Polska, Europa i Kościół między nihilizmem a islamem, Kraków 2017.

Lisicki P., Grób rybaka. Śledztwo w sprawie największej tajemnicy watykańskich podziemi, Warszawa 2019.

Lohfink G., Jakie argumenty ma nowy ateizm? Krytyczna dyskusja, przekład J. Machnacz, Wrocław 2009.

McGrath A., Bóg Dawkinsa. Geny, memy i sens życia, przekład J. Gilewicz, Kraków 2008.

Messori V., Opinie o Jezusie. „A wy za kogo mnie uważacie?”, przekład T. Jania, Kraków 1994.

Messori V., Dlaczego wierzę? Życie jako dowód wiary, przekład M. Wójcik, Kraków 2009.

Pabjan T., Anatomia konfliktu. Między nowym ateizmem a teologią nauki, Kraków 2016. 
Powracanie apologii, red. M. Skierkowski, Płock 2013.

Rożdżeński R., Ateizm, czyli wiara negatywna. Ateistyczne przeświadczenia z perspektywy pytań granicznych, Kraków 2016.

Seweryniak H., Teologia fundamentalna, t. I, Warszawa 2010.

Seweryniak H., Apologia wiary i nowa ewangelizacja, „Communio” 1/2014, s. 5-20. Seweryniak H., Apologia apologii „,na dziennikarstwie”, w: Debaty UKSWordzkie, cz. 2, red. J. Sobkowiak, Warszawa 2017, s. 7-53.

Seweryniak H., Apologia i dziennikarstwo, Warszawa 2018.

Sieczkowski T., Nowy ateizm. Rekonstrukcja światopoglądu, Łódź 2018.

Socci A., Śledztwo w sprawie Jezusa, przekład K. Kubis, Kraków 2010.

Socci A., Wojna przeciwko Jezusowi, przekład A. Gogolin, Kraków 2012.

Spaemann R., Wstęp, w: G. Kuby, Globalna rewolucja seksualna. Likwidacja wolności w imię wolności, przekład D. Jankowska, J. Serafin, Kraków 2012, s. 7-9.

Terlikowski T.P., Moralny totalitaryzm, Warszawa 2006.

Terlikowski T.P., Nowa kultura życia. Apologia bioetyki katolickiej, Warszawa 2009. Terlikowski T.P., Faktura na zabijanie. Współczesny przemysł śmierci, Bytom 2013. Terlikowski T.P., Sprawa profesora Chazana. Kulisy manipulacji. Warszawa 2014. Wiederkehr des Atheismus. Fluch oder Segen für die Theologie?, red. M. Striet, Freiburg im Breisgau 2008.

Wobec nowego ateizmu, red. I. Bokwa, M. Jagodziński, Warszawa 2011.

Zięba M., Kościół między gender a genderyzmem, w: tenże, Kłopot za kłopotem. Katolik w dryfującej Europie, Poznań 2015, s. 25-43.

Zięba M., Od pacyfizmu do świętej wojny, czyli 10 tez o religii i przemocy, w: tenże, Kłopot za kłopotem. Katolik w dryfującej Europie, Poznań 2015, s. 157-184. 